\title{
Does the Implementation of Corporate Governance Moderate the Relationships of Ownership Structure, Capital Structure and Firm Values of Listed Manufacturing Companies in Indonesia?
}

\author{
Munajat Mubaraq ${ }^{1, *}$, Sri Mangesti Rahayu ${ }^{2}$, Muhammad Saifi $^{3}$, Ari Darmawan ${ }^{3}$ \\ ${ }^{1}$ Doctoral Program of Business Administration, Brawijaya University Malang, Indonesia \\ ${ }^{2}$ Professor - Doctoral Program of Business Administration, Brawijaya University, Malang, Indonesia \\ ${ }^{3}$ Lecturer - Doctoral Program of Business Administration, Brawijaya University, Malang, Indonesia \\ *Corresponding author. Email: munajat@student.ub.ac.id.com
}

\begin{abstract}
This study aims to examine corporate governance's role as a moderating variable in determining firm value, such as ownership structure and capital structure. Indonesian stock exchange manufacturing companies from 2014 to 2018 were used in this study. The data used was panel data, with data analysis carried out using the WarpPLS program. The results showed that the ownership structure had a significant effect on capital structure while ownership structure and capital structure had no significant effect on firm value. Ownership structure moderated by corporate governance has no significant impact on firm value. Capital structure moderated by corporate governance also has no significant impact on firm value. New findings from this research show that corporate governance cannot moderate the determinants of firm value, such as ownership structure and capital structure.
\end{abstract}

Keywords: Corporate Governance, Ownership Structure, Capital Structure, Firm value

\section{INTRODUCTION}

The growth rate of shares of manufacturing companies on the Indonesia Stock Exchange has fluctuated due to the global economy's continued development over the past five years. With these fluctuations, stock prices represent company performance, and firm value is a significant concern. This concern is very reasonable, considering that until the end of 2019 the global economy had shown no signs of improvement.

The shareholders (principal) leave the firm's duties to the manager (agent) to achieve its goals. Managers are encouraged by shareholders to make decisions to maximise shareholder capital [9]. This also creates a conflict of interest known as the agency principle. An agency relationship occurs when an individual or other entity is employed by one or more people called the principal [11]. The proportion of share ownership controlled by management will influence company policy, which will undoubtedly affect how it does it. Managerial ownership will enable management to increase the efficiency of the company as it is in their direct ownership. The firm value will be enhanced by increasing the company's success [10]. This firm value is influenced by several factors such as the company's ownership structure and capital structure.

The implication is that ownership structure affects the capital structure because, according to [21], through the Pecking Order Theory, company authority is exercised using internal funds in the form of profits. If needed externally, the company will issue debt. Ownership by managers will affect the use of debt. Besides manager ownership, the ownership structure indicators used in this study are institutional ownership and public ownership. The composition of the ownership structure can influence debt policy. The composition of the ownership structure also affects firm value.

According to the Agency Theory, if both groups (management and owners) can maximise their work, there is good reason to believe that management will not always act in their owners' best interests [16]. To avoid this, Ownership Structure can play a role in reducing problems with asymmetric information. 
On the other hand, the capital structure can affect firm value. According to the Trade-Off Theory, debt will increase the company's value, where increased debt will directly affect the increase in firm value where the company is considered to have made many investments that can increase company value [19].

Bases the implementation of Corporate Governance on the Agency Theory; this theory explains the relationship between management and company owners [16]. Management as an agent is responsible for optimizing the company owner's profit (principal) to get compensation after the contract. There are different interests in the company where each party tries to improve or maintain welfare. Information asymmetry occurs between management and owners, which enables management to carry out earnings management.

Corporate governance can be a tool for managing the use of debt in a company. Using debt itself must be regulated because if there is too much debt, it can endanger the company and reduce its value. The independent commissioner and the audit committee can approve management to increase the company's debt.

Based on the results of previous studies that contradict the factors that influence firm value, this study considers corporate governance as a moderating variable in influencing firm value. This is due to the possibility of inconsistency due to direct or indirect influence on firm value. Therefore, this study aims to determine the moderating role of corporate governance variables in the relationship between ownership structure and capital structure that affect firm value.

\section{THEORETICAL REVIEW AND HYPOTHESIS DEVELOPMENT}

\subsection{Corporate Governance}

Good Corporate Governance (GCG) is a sum of rules regulating the relationship of rights and responsibilities between states, owners, creditors, staff management, and other internal and external interests, In other words, a system that directs the company and controls it [4]. According to [23], GCG is a scheme (input, process, output) and a set of rules governing the relationship between the stakeholders, particularly in the narrow sense of the shareholder relationship, The Commissioners' Board and the Board of Directors for the achievement of the company's goals.

\subsection{Ownership Structure}

[16] states that it is possible to use the Ownership Structure to reduce agency costs arising from agency problems. The ownership structure (insider ownership and institutional ownership) will align the interests of management with those of the shareholders. The ownership structure is an essential mechanism for controlling managers' behavior, so that they act carefully and work more effectively to increase shareholder wealth.

\subsection{Capital Structure}

Funding Decisions According to [9], financial managers' second primary responsibility is to raise funds needed by the company for investment and operations. Therefore managers must be able to consider the composition of the use of debt with their capital. [23] state that the funding decision is related to the company's decision to find funds to finance investment and determine funding sources' composition. Using debt or leverage is external financing to finance company activities.

\subsection{Firm value}

Firm value is the stock market value because the firm value can provide maximum prosperity for shareholders if their share price increases. The higher the share price, the greater the shareholders' worth. To achieve firm value, investors generally leave their management to professionals. [26] state that firm value is justified by the signalling theory, where the firm value will provide a high value if it is supported by a sound signal from the internal company.

\subsection{Hypothesis Development}

\subsubsection{Effect of Ownership Structure on Capital Structure}

The effect of ownership structure on the capital structure has been proven empirically by [5], [6], and [7]. Managerial ownership significantly positively affects the choice of long-term debt over equity [7]. [6] shows that insider ownership has a significant positive effect on total liabilities. [5] indicates that Institutional Ownership has a significant positive impact on leverage. Based on the theoretical and empirical studies that have been described, it is predicted that ownership structure affects the capital structure, so the study hypothesis is formulated:

\section{Hypothesis 1: Ownership Structure has a significant} effect on Capital Structure

\subsubsection{Effect of Ownership Structure on Firm value}

Ownership structure affects firm value. This has been proven empirically by [13], [15], and [17]. [15] show that institutional ownership has a significant positive effect on firm value denoted by the MBA (Market to Book Asset). [17] show that institutional ownership and public ownership significantly affect firm value with the Tobin'Q indicator. Meanwhile, [13] shows that institutional ownership has a significant positive impact on firm value with the Tobin'Q indicator. The study hypothesis is formulated as follows, based on the explanation above: 
Hypothesis 2: Ownership Structure has a significant effect on Firm value

\subsubsection{Effect of Capital Structure on Firm value}

Capital structure affects firm value. This has been proven empirically by [14], [15], and [22]. [15] show that leverage has a significant positive effect on firm value with the market to book ratio indicator. [22] shows that the debt to equity ratio significantly affects firm value with the profitability indicator. Meanwhile [14] shows that leverage has a significant negative impact on firm value with the market to book ratio indicator. Based on theoretical explanations and empirical studies, it is predicted that the capital structure will affect firm value in the formulation of the hypothesis as follows:

\section{Hypothesis 3: Capital Structure has a significant} effect on Firm value

\subsubsection{Effect of Ownership Structure on Firm value moderated by Corporate Governance}

The study of moderation of corporate governance on ownership structure on firm value is one novelty in this study. Implementing corporate governance in companies reduces agency costs due to the owner's distrust of agents. Ownership structure is influenced by implementing corporate governance to affect firm value.

Hypothesis 4: Corporate Governance can moderate relationship ownership structure to firm value

\subsubsection{Effect of Capital Structure on Firm value moderated by Corporate Governance}

The study of the moderation of corporate governance on the effect of capital structure on firm value is one of its novelties. Implementing corporate governance in companies influences management to prioritise capital structure policies, which can increase firm value. Based on these arguments, it is shown that implementing appropriate corporate governance on capital structure affects firm value.

Hypothesis 5: Corporate Governance can moderate the relationship between capital structure to firm value

\section{RESEARCH METHODOLOGY}

\subsection{Types and Data Sources}

This study has aims to investigate and explain the effect of exogenous variables (X) on endogenous variables $(\mathrm{Y})$, so the type of research used is explanatory research. According to [24], explanatory research explains the relationship between research variables and research hypotheses formulated previously. The data required is secondary data that comes from companies taken as research samples. The data required is financial data documented by the company; documentation is used to collect the data. Researchers collected data from company financial report documents and annual reports, company firm value profiles and IDX fact books for 2014 - 2018. The Indonesian Capital Market Directory and was relevant to the needs and objectives of this research.

\subsection{Population and Samples}

The population in this study are manufacturing companies listed on the Indonesia Stock Exchange between 2014 and 2018, amounting to 141 companies. Samples are subsets of certain group members that are part of the population, which are selected for analysis through sampling techniques that fit the research objectives.

The purposive sampling method was used with the criteria of listed active companies on the Indonesia Stock Exchange throughout the study period from 2014 to 2018. The companies used in the research published financial statements continuously, and always profit. The selected data included 64 companies.

\subsection{Variables and Measurements}

This study uses two Independent variables, namely (1) Ownership Structure, the distribution of share ownership of a company and (2) Capital structure, the composition of debt and equity as a source of corporate funding to finance investment. The dependent Variable is Firm value, which is a form of share price by a company in a certain period. One moderation variable is corporate governance, which a set of rules that formulate the influence between shareholders, managers, creditors, government, employees and other interested parties both internally and externally regarding their rights and responsibilities.

Table 1. Measurement of Variables

\begin{tabular}{|c|c|c|c|}
\hline Variable & Indicator & Measurement & Sources \\
\hline \multirow[t]{2}{*}{$\begin{array}{l}\text { Ownership } \\
\text { Structure }\end{array}$} & $\begin{array}{l}\text { Institutional } \\
\text { Ownership }\end{array}$ & $\begin{array}{l}\text { Institutional } \\
\text { share / Total } \\
\text { Share }\end{array}$ & [7] \\
\hline & $\begin{array}{l}\text { Managerial } \\
\text { Ownership }\end{array}$ & $\begin{array}{l}\text { Managerial } \\
\text { share / Total } \\
\text { Share }\end{array}$ & [20] \\
\hline $\begin{array}{l}\text { Capital } \\
\text { Structure }\end{array}$ & $\begin{array}{ll}\text { Total } & \text { Debt } \\
\text { Ratio } & \\
\end{array}$ & $\begin{array}{l}\text { Total debt } \\
\text { Total assets }\end{array}$ & [12] \\
\hline $\begin{array}{l}\text { Corporate } \\
\text { Governance }\end{array}$ & $\begin{array}{l}\text { Proportion of } \\
\text { Independent } \\
\text { Commissioner }\end{array}$ & $\begin{array}{l}\text { Independent } \\
\text { Commissioner } \\
\text { / } \\
\text { Total Members } \\
\text { of the Board of } \\
\text { Commissioners }\end{array}$ & [27] \\
\hline Firm Value & Stock Price & Closing Price & [8] \\
\hline
\end{tabular}

\subsection{Data Analysis Method}

Data analysis using the Structural Equation Model PLS (Partial Least Square) analysis using WarpPLS [25]. 


\section{RESULTS AND ANALYSIS}

\subsection{Indicator Exploration Results for Each Variable}

The results of this exploratory analysis show in full the value of the factor load and component weights for each variable as in the following table 2 :

Table 2. Exploration Results of Indicators for Each Variable in the WarpPLS Model

\begin{tabular}{|c|c|c|c|}
\hline Variable & Indicator & $\begin{array}{c}\text { Loading/ } \\
\text { Weight }\end{array}$ & p-value \\
\hline $\begin{array}{c}\text { Ownership } \\
\text { Structure }\end{array}$ & $\begin{array}{c}\text { Institutional } \\
\text { Ownership }\end{array}$ & 0.05 & $<0.001$ \\
\cline { 2 - 4 } & $\begin{array}{c}\text { Managerial } \\
\text { Ownership }\end{array}$ & 1.034 & $<0.001$ \\
\hline $\begin{array}{c}\text { Capital } \\
\text { Structure }\end{array}$ & Total Debt Ratio & 1,000 & $<0.001$ \\
\hline $\begin{array}{c}\text { Corporate } \\
\text { Governance }\end{array}$ & $\begin{array}{c}\text { Proportion of } \\
\text { Independent } \\
\text { Commissioner }\end{array}$ & 1.000 & $<0.001$ \\
\hline Firm Value & Stock Price & 1.000 & $<0.001$ \\
\hline
\end{tabular}

Based on the results of the analysis in Table 2, it can be seen that all indicators give significant results and are ready for further analysis.

\subsection{Model fit and quality indices model WarpPLS}

In the WarpPLS analysis there is a fit model size and quality index, as in the following table:

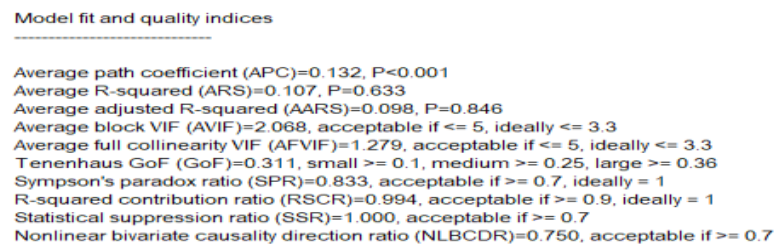

Figure 1 Model fit and quality indices model WarpPLS

Figure 1 shows that the model is fit, that is, all the fit and quality indices models are fulfilled. Thus, the model is said to be good and can explain the phenomena (systems) that are studied and can be used for hypothesis testing.

\subsection{Hypothesis Testing Results}

The results of the hypothesis testing are shown in table 3 .

Table 3. Hypothesis Testing Results

\begin{tabular}{|c|c|c|c|}
\hline Hypothesis & Coefficient & P-value & Explanation \\
\hline 1 & $-0.226^{*}$ & $<0.001$ & Significant \\
\hline 2 & $-0.119 \mathrm{~ns}$ & 0.194 & Non-Significant \\
\hline 3 & $0.013 \mathrm{~ns}$ & 0.428 & Non-Significant \\
\hline
\end{tabular}

\begin{tabular}{|c|c|c|c|}
\hline 4 & $0.074 \mathrm{~ns}$ & 0.085 & Non-Significant \\
\hline 5 & $0.149 \mathrm{~ns}$ & 0.381 & Non-Significant \\
\hline
\end{tabular}

\section{DISCUSSION}

\subsection{Effect of Ownership Structure on Capital Structure}

Hypothesis 1 of this study was accepted because the effect of Ownership Structure on Firm value gets a coefficient of -0.226 with $\mathrm{P}$-value $<0.001$. P-value < 0.05 , with the negative direction of the coefficient indicates that Ownership Structure affects capital structure significantly.

The implication of this study supports the Pecking Order Theory, which states that company managers have information about the prospects of the company and are more likely to use debt because it will be responded to positively by the market. Conversely, some investors invest in companies with low debt because of the low risk of default [21].

The implication of this study supports the results of research conducted by [1], [2] and [3], which state that ownership structure has a significant negative effect on capital structure.

\subsection{Effect of Ownership Structure on Firm value}

Hypothesis 2 of this study was rejected because the effect of Ownership Structure on Firm value gets a coefficient number of -0.119 with $\mathrm{P}$-value $=0.194$. $\mathrm{P}$ value $>0.05$, with negative direction of coefficient indicates that Ownership Structure affects Firm value insignificantly.

The results are not in line with the research of [15], which shows that ownership structure via institutional affects the positive statistical significance of company value. These findings also contradict the research of [20] which states that there is a significant positive relationship between Ownership Structure and company value; [13] states: Ownership Structure has a significant positive effect on firm value.

\subsection{Effect of Capital Structure on Firm value}

Hypothesis 3 of this study was rejected because of the influence of capital structure on firm value. The coefficient number is 0.013 with $\mathrm{P}$-value $=0.085$ obtained. P-value $>0.05$ with the positive direction of the coefficient indicates the influence of capital structure on firm value is insignificantly positive. This means the capital structure will not give a significant result on firm value. The implication of this study does not support the research of [15], which states that capital structure, as measured by leverage, has a positive and significant 
impact on the company's firm value, meaning that an increase in the leverage will raise the company's value. These findings contradict [22] that capital structure with indicators of debt-equity ratio significantly affects firm value; and [14] that capital structure has a statistically significant effect on firm value with a positive effect as measured by the market to book ratio indicators at significant levels. But the research in line with [18] mentions that Capital Structure affects Firm Value insignificantly even in the opposite direction.

\subsection{Effect of Ownership Structure on Firm Value moderated by Corporate Governance}

This study rejects hypothesis 4 because the moderation of corporate governance coefficient number is 0.074 with $\mathrm{P}$-value $=0.085$ obtained. $\mathrm{P}$-value $>0.05$, with the positive direction of coefficient, indicates that corporate governance cannot moderate the relationship of ownership structure on firm value.

Corporate governance moderation on the effect of ownership structure on firm value has an insignificant positive effect. The theoretical implication of this empirical is that increasing corporate governance will not strengthen or weaken the relationship of ownership structure and firm value. The findings of this study do not strengthen the Agency Theory, which states that the two groups (management and owners) try to maximise their utility, so there are strong reasons to believe management will not always act in the best interests of the owner [16]. Increasing corporate governance will increase the control exercised by external parties to reduce agency conflicts and does not affect ownership structure in increasing firm value.

\subsection{Effect of Capital Structure on Firm Value moderated by Corporate Governance}

This study rejects hypothesis 5 because the moderation of corporate governance coefficient number is 0.149 with $\mathrm{P}$-value $=0.381$ obtained. $\mathrm{P}$-value $>0.05$, with the positive direction of coefficient, indicates that corporate governance cannot moderate the capital structure's relationship on firm value.

Corporate governance moderation on the effect of capital structure on firm value has an insignificant positive effect. The theoretical implication of this empirical is that increasing corporate governance will not strengthen or weaken the relationship of capital structure and firm value. The findings of this study do not strengthen the Agency Theory, which states that the two groups (management and owners) try to maximise their utility, so there are strong reasons to believe management will not always act in the best interests of the owner [16]. Increasing corporate governance will increase the control exercised by external parties to reduce agency conflicts and does not affect debt policies in increasing corporate value.

\section{CONCLUSION}

Ownership Structure has a significant effect on capital structure. Meanwhile, both ownership structure and capital structure give insignificant effect on firm value. The moderation of corporate governance has an insignificant impact on the effect of ownership structure on firm value.

\section{REFERENCES}

[1] Chen, R. C., \& Steiner, T., Managerial Ownership and Agency Conflicts: A Nonlinear Simultaneous Equation Analysis of Managerial Ownership, Risk Taking, Debt Policy, and Dividend Policy", Financial Review, 1999, 34.

[2] Shoaib, K., \& Yasushi, S., Ownership and capital structure of Pakistani non-financial firms. Financial Internet Quarterly "e-finance" 2016, 12(1), 57 - 67.

[3] Tariq, R., \& Rasheed, M. S., Ownership Structure, Corporate Governance and Capital Structure: Evidence from Countries having FPI in Pakistan. Journal of Insurance and Finacial Management, 2018, 3(5), 18-28.

[4] Organization for Economic Cooperation and Development. OECD Principles of Corporate Governance 2004. The OECD Paris. 2004

[5] Reza, S. M. R., \& Tularam, G. An analysis of the relationships between ownership structure and capital structure of the global water industry. 22nd International Congress on Modelling and Simulation, Hobart, Tasmania, Australia, 3-9 December 2017.

[6] Shyu, J., Ownership structure, capital structure, and performance of group affiliation. Managerial Finance. 2013

[7] Bokpin, G. A., \& Arko, A. C., Ownership structure, corporate governance and capital structure decisions of firms. Studies in Economics and Finance, 2009

[8] Black, F.. Uniqueness of the price level in monetary growth models with rational expectations. Journal of Economic Theory, 1974, 7(1), 53-65.

[9] Brealey, R. A., Myers, S. C., \& Marcus, A. J., Fundamentals of Corporate Finance., 2012

[10] Brigham, F.E., and Daves. R.P., Intermediate Financial Management. Eight Edition. Mc.Graw Hill, 2013.

[11] Brigham, E. F., \& Houston, J. F., Study Guide for Brigham/Houston's Fundamentals of Financial Management, Concise Edition, 7th. Cengage Learning, 2011

[12] Horne, J. C. V., \& Wachowicz Jr, J. M., Prinsipprinsip Manajemen Keuangan. Edisi 13, buku 1. Salemba Empat, Jakarta, 2012 
[13] Byun, H. S., Lee, J. H., \& Park, K. S., Ownership Structure, Intensive Board Monitoring, and Firm Value: Evidence from K orea. Asia-Pacific Journal of Financial Studies, 2013, 42(2), 191-227.

[14] Ghalandari, Kamal., The moderating effect of growth opportunities on the relationship between capital structure and dividend policy and ownership structure with firm value in Iran: Case study of Tehran Securities exchange. Research of Journal Applied Sciences, Engineering and Technology, 2013, 5(4), 1424-1431.

[15] Iturriaga, F., \& Crisóstomo, V., Do Leverage, Dividend Payout, and Ownership Concentration Influence Firms' Value Creation? An Analysis of Brazilian Firms. Emerging Markets Finance \& Trade, 2010, 46(3), 80-94.

[16] Jensen, M. C., \& Meckling, W. H., Theory of the firm: managerial behavior, agency cost and ownership structure. Journal of financial economics, 1976, 3(4), 305-360.

[17] Lorca, C., Sánchez-Ballesta, J. P., \& García-Meca, E., Board effectiveness and cost of debt. Journal of business ethics, 2011, 100(4), 613-631.

[18] Machfiro, S., \& Sukoharsono, E. G., The Effect of Financial Variables on The Company's Value (Study on Food and Beverage Companies that are listed on Indonesia Stock Exchange Period 20082011). Jurnal Ilmiah Mahasiswa, 2012, FEB, 1(1).

[19] Modigliani, F., \& Miller, M. H., Corporate income taxes and the cost of capital: a correction. The American economic review, 1963, 53(3), 433-443.

[20] Mollah, S., Keasey, K., \& Short, H., The influence of Agency costs on dividend policy in an emerging market: Evidence from the Dhaka stock Exchange.
Paper of Workshop at the University of Oslo Norway. 2000

[21] Myers, S. C., Capital structure puzzle (No. w1393). National Bureau of Economic Research, 1984

[22] Oluwagbemiga, O. E., Perceived relationship between corporate capital structure and firm value in the Kenyan listed companies. Research Journal of Finance and Accounting, 2013, 4(19), 157-164.

[23] Saifi, M., Suhadak, S. M. R., \& Handayani, S. R., The Effect of Corporate Governance and Investment Opportunity Set on Capital Structure, Dividend Policy, and Firm Performance (A Study on GoPublic Manufacturing Companies in Indonesia Stock Exchange). International Journal of Management and Administrative Sciences (IJMAS), 2016, 3(02), 53-63.

[24] Singarimbun, M., \& Effendi, S., Metode Penelitian Survai Edisi Revisi. Jakarta: Lp3ES, 1995

[25] Solimun, Fernandes, A.A.E., \& Nurjannah., Metode Statistika Multivariat Permodelan Persamaan Struktural (SEM) Pendekatan WarpPLS. UB Press, Malang, 2017

[26] Sukoco, H., Nasir, M., \& PRASETIONO, P., Analisis Pengaruh Debt to Equity Ratio, Profitabilitas, Firm Size, dan Likuiditas terhadap Nilai Perusahaan melalui Mediasi Dividend Payout Ratio (Studi pada Industri Manufaktur di Bursa Efek Indonesia Periode Tahun 2009-2011) (Doctoral dissertation, Diponegoro University), 2013

[27] Abor, J., \& Fiador, V., Does corporate governance explain dividend policy in Sub-Saharan Africa?, International Journal of Law and Management, 2013. 